\title{
Birds, beasts and bovines: three cases of pastoralism and wildlife in the USA
}

\author{
Lynn Huntsinger ${ }^{1 *}$, Nathan F Sayre ${ }^{2}$ and JD Wulfhorst ${ }^{3}$
}

\author{
* Correspondence: huntsinger@ \\ berkeley.edu \\ ${ }^{1}$ Department of Environmental \\ Science, Policy, and Management, \\ University of California, 130 Mulford \\ Hall, Berkeley, CA 94720, USA \\ Full list of author information is \\ available at the end of the article
}

\begin{abstract}
Background: Pastoralism in the USA began coincidently with the initiation of profound ecological change resulting from colonization in the sixteenth century. Relationships between pastoralism and wildlife conservation in three different contexts of land tenure, environmental legacy, and geography are examined.

Results: On the federal rangelands of the Intermountain West, based on limited scientific information, wildlife policy has been interpreted to require separation of native bighorn sheep from livestock to prevent disease transmission. Ignored are the possible long term and broad scale impacts of removing grazing on the ecosystem and the 'social disturbance' to local communities. In southwestern deserts, the implementation of wildlife policy exemplifies the contradictions between conservation of individuals versus populations, and fire suppression and grazing removal as 'inactions' requiring no review versus grazing and burning as 'actions' requiring regulation and control. In California's Mediterranean rangeland, wildlife policy under the Endangered Species Act is at once a regulatory burden and an opportunity for ranchers. The opportunities result from an evolving recognition that cessation of grazing can harm wildlife.
\end{abstract}

Conclusions: In all three cases, the environment has changed and is changing due to ecosystem engineering that alters the resources available to wildlife and plant species. Grazing offers potential benefits as a management tool, and pastoralism a means of maintaining un-fragmented landscapes. Yet, absent adequate ecological information, the assumptions of innate conflict between livestock and wildlife, and that cessation of grazing is not an action, as well as the norms of a politically popular yet ecologically unsupportable discourse of restoration, fill in the gaps.

Keywords: Endangered Species Act, Grazing, Land use, Ecosystem engineering, Succession, Public lands management, Restoration, Wildlife conservation

\section{Introduction}

On a global scale, pastoral lands are generally extensive, of low productivity, and of ambiguous ownership. The pastoral regions in the USA are no exception. Traditional forms of food production from pastoral lands, while uniquely suited to the aridity and unpredictability characteristic of rangelands (Behnke et al. 1993), are low in production on a per hectare basis. Lands used for grazing are at best vast, allowing mobility and flexible use of the landscape to accommodate climatic uncertainties (Niamir-Fuller 1998). A large proportion of US arid rangelands in the West are in government ownership and, until recently, were managed largely for livestock grazing, mining, and rural recreation. 
Transhumant grazing patterns using public deserts and mountains and private watered lands are common (Huntsinger et al. 2010).

Today, alternate uses for the land often seem to offer greater returns than livestock grazing. Mining, cultivation, and nature-based recreation are common competing land uses around the world. Where land is irrigable in the USA, it is almost always farmed and has long been so though technological advances in irrigation methods feed expansion of cultivated lands. Mining is an encroachment on rangelands that is gaining worldwide attention and is a major competitor for US rangelands. Recreation and tourism are growing and provide income to landowners and governments. In the USA, many recreationists have urban roots and may fear or dislike livestock. The expansion of residential areas into US rangelands brings pastoralism under new kinds of scrutiny as new neighbors are drawn to recreate on nearby lands and expect to be shielded from agricultural activities, wildfires, and other natural hazards. In an era of mass extinction, rangelands are looked to as refugia, and 'the marginal lands that were previously the province of pastoralists are increasingly coming into focus as reserves of biodiversity' (Blench 2001). Large areas of US public rangeland have been withdrawn from grazing or had reductions in grazing in order to be managed for wildlife and nature-based recreation. Can mobile pastoralism persist under such conditions?

Wildlife conservation and mobile pastoralism require similar landscape configurations at the landscape scale. They rely on large areas, travel corridors, water supplies, cover, and consumable vegetation. Efforts to protect pastoral landscapes in and of themselves benefit whole suites of species. However, within this framework, at smaller scales, tradeoffs and conflicts occur. As an ecological process, grazing may change vegetation, soils, waterways, and the species profile. Disease transmission between livestock and wildlife may occur. Pastoralists and their activities, including hunting, predator control, fence construction, and water development, directly and indirectly influence wildlife. In the USA, this brings grazing and its accouterments within the scope of the Endangered Species Act and other laws and regulations that require the protection of rare animal species on private land and rare plant and animal species on government land.

\section{Methods}

We focus on three case studies of the relationships between pastoralist production and wildlife conservation in the USA. Because of the institutional setting in the USA, exemplified by the Endangered Species Act and its outgrowths, the push for wildlife conservation offers pastoralists the proverbial double-edged sword: for some, the push for biodiversity is a threat to grazing practices and territory; for others, it may prove the salvation of the pastoralist enterprise as part of a diversification of income streams. Here, we explore the particular configuration of environmental, social, and institutional settings that support these alternative outcomes in the USA by examining wildlife-pastoralist relationships in Mediterranean, southwestern desert, and cold desert steppe regions (Figure 1).

\section{Background}

\section{Ranching in the arid West}

In the arid lands of the American West, those who graze extensive rangelands with herds of livestock are sedentary, part of the developed economy, and often do not 


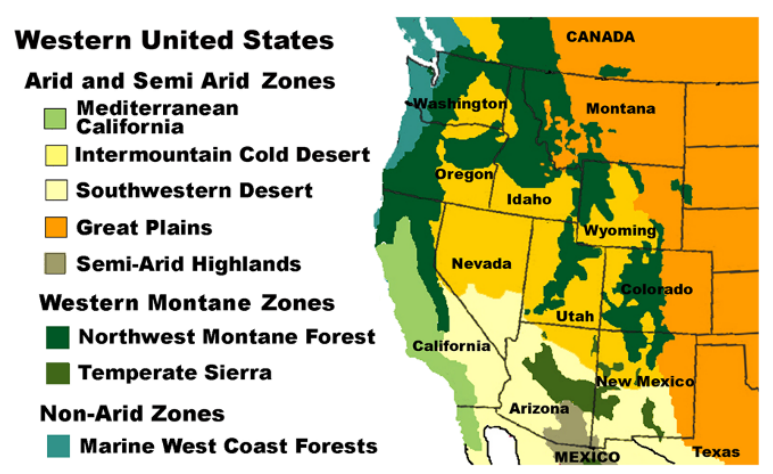

Figure 1 Major vegetation zones of the western USA. The three case studies are in Mediterranean California rangelands, Southwestern desert rangelands, and the Intermountain cold desert steppe.

depend on the livestock enterprise for a livelihood (Huntsinger et al. 2010). Yet, ranchers using extensive rangelands share many of the attributes that have been identified as characteristics of traditional pastoralists, including strong identification with livestock husbandry as a way of life, distinct subcultures, a general belief that society is somewhat hostile toward them and their activities, mobility and use of land without secure tenure, a mistrust of governmental authority, reciprocal social relations including a tradition of sharing pastures in times of crisis, and dependence on peers (Huntsinger et al. 2010).

The majority of arid US rangelands are under the ownership and administration of federal, state, or local government as a result of historic processes of land allocation. The US Forest Service controls approximately 78 million ha (US Department of Agriculture Forest Service 2011) of mostly montane lands, and the US Bureau of Land Management controls 106 million ha of mostly desert and steppe (United States Department of the Interior Bureau of Land Management 2011). These lands are also used for recreation, mining, and forestry. Additional millions of hectares are part of Indian and military reservations, and are often grazed by livestock. The better-watered lands are in private holdings often as small parcels located on water and surrounded by government land. Typically, these are used in conjunction with grazing permits on government land in a cyclical annual pattern of using highlands, lowlands, and pasture to provide forage all year. The majority of rangeland livestock producers graze herds of cattle, often of English breeds. Typically, ranchers own 200-300 cows and sell the calves from them each year. A distant and declining second is sheep production.

Surveys of US ranchers have shown them to be strongly interested in wildlife and motivated to undertake 'wildlife habitat improvement' practices (Ferranto et al. 2011; Liffmann et al. 2000; Rowe et al. 2001; Kreuter et al. 2006). The definition of wildlife may be centered on game animals-exemplified by the comment of one rancher interviewed in California when he said 'I manage for the good wildlife'. In fact, the main purpose of ranch ownership for some is to have a private hunting and fishing area (Gosnell and Travis 2005). Ranchers may charge people to hunt on their land though the animals are the property of the state. This income can be a significant augmentation to income from livestock. Because better-watered lands are often in private ranch ownership, private lands may be the richest wildlife habitat in a region (Maestas et al. 2003). 


\section{Wildlife policy and the Endangered Species Act}

In general, native wildlife in the USA whether on private or public land is regulated by the federal and state governments. Government agencies are responsible for managing all wildlife and habitat on public lands. On private lands, due to the historical evolution of wildlife regulation, the details of state regulatory schemes vary from state to state. Prior to passage of the Lacey Act in 1900, which regulated commerce in wildlife, many wildlife specimens were captured live, traded, sold, and considered privately owned property. The offspring of these privately owned animals were also considered private property, which explains the case of the American bison (Bison bison), the vast majority of which are owned privately like livestock (Lueck 2002). Many exotic animals imported from abroad prior to regulation and even herds of white-tailed deer (Odocoileus virginianus) continue to remain under private ownership in a similar manner. These privately owned animals can often be managed and harvested without the same regulations that govern other native wildlife that are regulated by state or federal government. Game ranching can occur with nonnative species, privately owned, or publicly regulated wildlife with oftentimes less restrictive regulations for privately owned wildlife than government regulated wildlife.

Relations between ranchers and wildlife today are strongly influenced by the Endangered Species Act of 1973. Under the Act, the federal government protects native species designated as endangered or threatened, and the habitats upon which they depend. Endangered means a species is in danger of extinction throughout all or a significant portion of its range. Threatened means a species is likely to become endangered within the foreseeable future. All species of plants and animals, except pest insects, are eligible for listing as endangered or threatened, with over 1,200 species currently listed. The Act makes it unlawful for a person 'to harass, harm, pursue, hunt, shoot, wound, kill, trap, capture, or collect' a listed animal without a permit, referred to as taking a listed animal or plant. Through regulations, the term harm is defined as 'an act which actually kills or injures wildlife. Such an act may include significant habitat modification or degradation where it actually kills or injures wildlife by significantly impairing essential behavioral patterns, including breeding, feeding, or sheltering'. Listed plants are not protected from take, although it is illegal to collect or maliciously harm them on federal land (United States Department of the Interior Fish and Wildlife Service 2011).

Two thirds of federally listed species have at least some habitat on private land. The federal government has developed an array of tools and incentives to encourage management activities that benefit listed and other at-risk species. Habitat Conservation Plans, an option added by a 1982 amendment, may be used by landowners, including private citizens, corporations, tribes, states, and counties, to develop property that is inhabited by listed species. Landowners may receive a permit to take such species incidental to otherwise legal activities, provided they have developed an approved plan. These include an assessment of the likely impacts on the species from the proposed action; the steps that the permit holder will take to avoid, minimize, and mitigate the impacts; and the funding available to carry out the steps. The idea is that such planning may benefit not only landowners but also species by securing and managing important habitat while allowing economic development that is planned to provide species conservation.

Safe Harbor Agreements were initiated in the 1990s to provide regulatory assurance for non-federal landowners who voluntarily aid in the recovery of listed species by 
improving or maintaining wildlife habitat. An agreement allows such landowners to carry on their usual activities without fear of being punished for take that is incidental to their ordinary management activities.

Conservation banks are lands that are permanently protected and managed as mitigation for the loss elsewhere of listed and other at-risk species and their habitat. Credits are supplied by landowners who enter into a Conservation Bank Agreement with the government that commits them to protect and manage their lands for one or more species. Developers and others who need to mitigate for adverse impacts to those same species may purchase conservation bank credits from willing sellers to meet their mitigation requirements (United States Department of the Interior Fish and Wildlife Service 2011). Use of conservation banks is common in Habitat Conservation Plans, and the plan is supposed to consider the proportion and distribution of lands set aside as conservation banks within the planning area and how that will affect wildlife conservation.

The law requires federal agencies to ensure that actions they authorize, fund, or carry out are not likely to jeopardize the continued existence of any listed species or result in the destruction or adverse modification of designated critical habitat of such species (United States Department of the Interior Fish and Wildlife Service 2011). This means that federal agencies are compelled to protect listed species regardless of other management goals, potentially leading to significant changes in allowed grazing. On private lands, the law generally comes into play when the landowner wants to carry out a regulated management activity or develop the land for other uses. Losses of individuals or habitat must be prevented or mitigated. Many states have created their own set of listed species and similar legislation to go with it, for example, the California Environmental Quality Act includes protection of species listed under state criteria.

On federal lands, there is a body of legislation, policy, and management directives that requires protection of native species in general. The National Forest Management Act of 1976 is now the primary statute governing the administration of national forests. It specifically requires national forests to maintain viable populations of 'native and desired nonnative vertebrate species...well distributed in the planning area.' The secretary of Agriculture's Policy on Fish and Wildlife (9500-4) directs the Forest Service to 'manage habitats for all native and desired nonnative plants, fish and wildlife species to maintain viable populations of each species; identify and recover threatened and endangered plant and animal species and to avoid actions which may cause species to become threatened or endangered.' Forest Service Sensitive Species Policy (FSM 2670.32) calls on national forests to assist states in achieving conservation goals for endemic species, to complete biological evaluations of programs and activities, avoid and minimize impacts to species with viability concerns, analyze significance of adverse effects on populations or habitat, and coordinate with states, the US Fish and Wildlife Service and the National Marine Fisheries Service. Similar policies apply on Bureau of Land Management and other federal lands.

\section{Results and discussion}

\section{California's Mediterranean rangelands: risks and opportunities}

More than 200 years of ecosystem engineering created novel relationships between pastoralists and wildlife in California. The actions of livestock and their owners have created an ecosystem state change that has modulated the flow of resources to a myriad 
of other species, fitting the classification of allogenic ecosystem engineering as defined by Jones et al. (1994). Jones et al. (1994) suggest that using the concept of ecosystem engineering to understand ecosystems is justified when it improves understanding of ecological interactions. In the case of California, using the concept of ecosystem engineering to examine the relationship between pastoralism and wildlife not only enhances understanding of the ecological interactions that shape the ecosystem but also offers critical insights for management and policy.

California's grassland and savanna ecosystems are in a novel and irrevocable state created by colonization and the importation of new animals and plants. This state change is one that follows on state changes engineered by thousands of years of indigenous management. Unlike pastoral regions in much of the world, livestock grazing has been part of California ecosystems for less than 300 years. Spanish importation of cattle and sheep into California began in 1769. California's Native Americans did not use domesticated grazing animals, and the flora and fauna they managed, largely with fire, were for the most part isolated from the rest of the world for millennia. Ecosystems were, thus, suddenly and heavily influenced by multiple post-contact impacts, including pastoralism, plowing, changes in fire regimes, reduction of native grazers like elk and antelope, and the introduction of aggressive species from the other Mediterranean regions of the world.

The native grasslands of the state have been invaded on a massive scale by aggressive grasses and broadleaves from the 'fertile crescent', plants that have survived and flourished despite thousands of years of widespread cultivation and livestock grazing. The role played by livestock grazing in the success of this invasion, relative to all the other factors that accompanied colonization, is debated (Bartolome and Jackson 2007); however, what is clear is that the grasslands have been profoundly changed by annual grass species that have largely supplanted native species. Pastoralism and farming had a definitive role in that seeds were carried in and on stock and in feed and crop seeds throughout California. Livestock grazing in some areas reduces the presence of shrubs and, by removing biomass, reduces the spread and occurrence of wild and deliberate fires. Grazing also creates soil disturbance, changes mineral cycling through manure deposition, and may favor one perennial species over another, which could have had an influence on some of the native perennial flora. These factors all contributed to the state change. Pastoralism brought over and, then, helped increase pastoralism-adapted flora from the Mediterranean Basin.

The actions of pastoralists have also created ecosystem change particularly through the engineering of water. Irrigation ditches, irrigation itself, and the construction of ponds are prominent examples of engineering associated with pastoralism. Water has been removed from some areas and transferred to others. Water from creeks that would otherwise dry up in summer is stored in ponds that last farther into the dry season, extending the grazing period for livestock. Ditches and pipes transfer water to ponds and water troughs, or to irrigated pastures. Cultivation is also associated with pastoralism to some extent; however, as cultivation usurps the ecosystem and changes it to an entirely anthropogenic state that is broadly recognized as such, it is not included in this analysis. Instead, we focus on the quasi-natural rangelands that are commonly subject to restoration discourse.

Environmentalists, scientists, and natural resource managers often perceive California rangeland ecosystems as in a condition that represents a deviation from a recoverable 
'natural' state. Frequent use of terms like 'degraded' reflects a normative view of ecosystem change that is based on the idea that a former 'pristine' state has been shifted in a linearly negative way to a 'lower' condition and remains in that lower state as long as the driver of change remains, returning to a higher state once the driver is removed. This way of seeing the ecosystem has been transformed into management practice, policy, and scientific inquiry that is part of a powerful discourse of 'restoring' California ecosystems by returning ecosystems to native flora. Unfortunately, while the engineers-livestock and pastoralists-may be and are being removed from the system, the engineered artifacts in the form of the changed grassland have an extremely long halflife-well beyond any anticipated time horizon.

\section{The default prescription}

An assumption of the restoration discourse has been that part of the restoration process must be reduction or elimination of livestock grazing and pastoralism. A movement to restrict or eliminate livestock grazing from sensitive areas and from all government lands has gained considerable momentum in the USA. This view can be linked to a classical Clementian succession model of vegetation change where deviation from the ideal end state or 'climax' can be reversed by the removal of the driver or 'disturbance' that caused the deviation. Livestock grazing has, as a result, been treated as an unnatural disturbance for decades. In line with this view, the removal of 'unnatural' livestock grazing has long been a default step on the path to managing for biodiversity conservation.

Decades of research has been unable to connect reduction or elimination of grazing to a significant revival of native species in California (Huntsinger et al. 2007). Returning to the ecosystem engineering concept, what took place is a state change from a grassland of native to introduced flora. This state change is in large part permanent: practically speaking, the nonnative annuals cannot be removed (Heady 1958, 1977). The shift had profound implications for the fauna that depended on the previous flora. As Jones et al. (1994) point out, such changes benefit some species and disadvantage others. The resources and habitat available to the native flora and fauna changed. The species found in California today are those that have successfully and rapidly coped with or benefited from this state change.

The ecologists, managers, and environmentalists of today, then, derive their understanding of California's flora and fauna from the existing state but generally without acknowledging or understanding its engineered origins. Removal of pastoralism does not stimulate a return to a pristine state nor does it maintain the existing second state but, instead, creates an entirely new third state where the artifacts of engineering persist, but the engineering agent is removed. Again, removal causes a modulation of resource flows, advantaging some species and disadvantaging others. Some of the species that have flourished in the engineered second state environment are lost as this new third state develops, and resource streams are altered. Ironically, studies are accumulating that show that a number of the state's rare species are among those disadvantaged by this shift to a new third ecosystem state (Barry 2011).

Another legacy of Spanish, Mexican, and American colonization is that California has a larger proportion of private landownership than is characteristic of much of the western USA. Half of the state is privately owned, and pastoralists, referred to as ranchers 
or range sheep producers, own an estimated 9 million ha out of the approximately 18.5 million ha of private land in the state (California Rangeland Trust 2011), mostly in the Mediterranean zone. However, there is growing pressure on even private landowners to manage for restoration, and as private and public lands are acquired for or shifted to conservation purposes, they become subject to restoration goals that include removal or restrictions on pastoralism. On such lands, the removal of grazing and water engineering can have profound and unanticipated impact on wildlife and plant species. As this has become more understood, new opportunities for pastoralists have opened up at least partly as a result of the Endangered Species Act. The following cases illustrate these points. The first, that of the California tiger salamander in the San Francisco Bay Area, is selected because its dependence on grazing and pastoralism is now widely recognized, and institutional mechanisms have been developed to create pastoralistfriendly conservation initiatives. The second, the case of the California Black Rail, is a newly unfolding saga of pastoralism and a rare species where the relationship of the species with grazing may prove more complex.

\section{The California tiger salamander: a case in point}

California has a disproportionately high percentage of threatened or endangered species compared to other states, and the majority of these occur on private lands (Scott et al. 1995; Dobson et al. 1997). One of these is the California tiger salamander (Ambystoma californiense). In the San Francisco Bay Area, most native habitat has been eliminated by urban expansion. Of the 155 California tiger salamander locality records in the eastern San Francisco Bay Area (Alameda and Contra Costa counties) where the wetland type was identified, 85\% (131 sites) were located in stock ponds (United States Department of the Interior Fish and Wildlife 2004). Stockponds have been created over the last 100 years

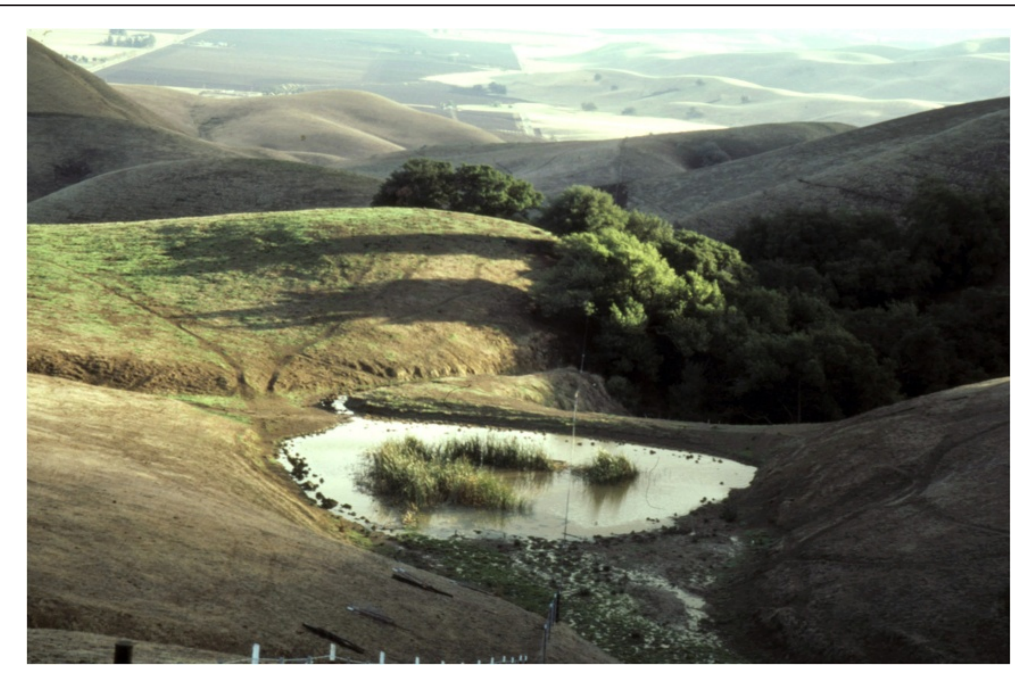

Figure 2 A stockpond in the San Francisco Bay Area. Cattle have grazed off the vegetation at the edge of the pond and muddied the water. Both conditions are now believed to benefit the endangered California tiger salamander. When bullfrogs are absent, stockponds are also crucial habitat for the threatened red-legged frog (Rana draytonii) (United States Department of the Interior Fish and Wildlife Service 2006). 
by developing springs or blocking small waterways, creating dams that hold water into the dry season (Figure 2).

The presence of an endangered or threatened species on a rancher's land can lead to apprehension on the part of the landowner. If the landowner chooses to develop the land, the species and habitat must be protected or the lost habitat must be mitigated under the Endangered Species Act. Obviously, this increases the costs of development and reduces the potential sale price of the land. In one famous case in California, environmental consultants inventorying species for a developer were caught secretly moving red-legged frogs to another location to reduce the costs of compliance with the Endangered Species Act (Lee 2001).

Even without concerns about the value of the land, the landowner may find management activities limited by the Act. In a famous case in timberlands, landowners preferred to eliminate potential habitat for an endangered bird before it could be identified on their land so that timber harvest practices would not be restricted (Lueck and Michael 2003). Enforcement of this Act and California species protection regulations is in part responsible for the fact that the US Fish and Wildlife Service and the California Department of Fish and Game are the conservation agencies that forest and rangeland landowners trust the least (Ferranto et al. 2012). Safe Harbor Agreements that allow landowners complying with certain requirements to carry on their usual activities without fear of being punished for take are an attempt to reduce the concerns of landowners. In the case of California ranchers and the tiger salamander, a special exemption was created for routine ranch practices (United States Department of the Interior Fish and Wildlife 2004), at least partly in recognition of the fact that without ranching, little habitat would remain.

However, the Act also opens up the possibility of selling conservation bank credits from ranch lands, as one way to 'mitigate' is to purchase or create habitat for the endangered or threatened species elsewhere. Some ranchers have sold 'mitigation easements' to earn some extra funds to support their ranching. An easement is a permanent change in the property title that limits or controls the use of a geographical area. While government wildlife officials are prohibited from entering a private landowner's land without permission, to participate in mitigation, or some conservation cost-share programs, a landowner must allow the species and its habitat to be verified on their land. At the California Society for Ecological Restoration Conference, a rancher related the following about going with a wildlife official to examine his stock pond for the presence of tiger salamanders:

We walked out to the pond and I saw it with fresh eyes. It was denuded, and muddy, and looked just terrible. I thought to myself, 'this is not going to be good.' However, when the wildife official put his net in the pond, it came out full of salamander larvae. The biologist said he had never seen so many larvae before.

Since these events, research and common experience have shown that tiger salamanders seem to prosper in grazed ponds. A survey of grazed and un-grazed ponds found them more common when vegetation was grazed and water was muddy (DiDonato 2007). Salamanders are able to move across the grassland when the grass is shorter, predatory insects cannot hide on emergent vegetation when it is grazed, and predators find it harder to target the amphibians when the water is not clear. In fact, salamanders 
have been found to disappear from fenced and restored ponds. Yet, grazed ponds do not conform to the classic image of a natural, wildlife-friendly pond. Ranchers selling conservation bank credits or mitigation easements on their lands are also often asked to restrict or eliminate grazing on the mitigation areas. One rancher related the following to students on a field trip in 2010:

I had serious problems paying the inheritance taxes on my land. I sold an easement for the protection of a stock pond I have that has salamanders in it. This pond was built by my grandfather, and was excellent for watering cattle. After I sold the easement, the representative from the wildlife agency came out to have a look. He said, 'well, let's talk about where to put the fence to keep the livestock out'. Now this pond had been grazed for decades, and salamanders were abundant.

After some struggle and various intercessions, the landowner was able to convince the agency to allow him to continue to graze the land. However, once designated as endangered species habitat, activities like pond maintenance can become a major struggle with bureaucracy. Ponds need to be cleared of sediment every so often, and dams need to be repaired. There are cost share funds available from the federal and state governments for improving wildlife habitat or environmental quality. Repair projects generally require five or six environmental permits, and the supervision of a wildlife biologist as part of a lengthy, expensive, and confusing process that brings the ranch under the scrutiny of a regulatory agency. Ranchers tell stories of long delays and, from their perspective, illogical and costly decisions. Some ranchers also fear that they could face new Endangered Species Act restrictions if they voluntarily improve habitat for endangered species. Evidence is accumulating that grazing is beneficial for many species of concern, yet the norms of the wildlife agencies in general run to the opposite view and are slow to change.

In response to these concerns, in one Bay Area county, the Resource Conservation District and Natural Resource Conservation Service, which administer cost-share funds from the government and provide technical advice to ranchers and farmers, developed a program to help ranchers cope with the paperwork and hassles in putting together funding for wildlife-sensitive pond maintenance and for understanding compliance requirements. This program, termed the 'Wildlife Friendly Pond' program, helps ranchers find funds from several sources so that as much as $90 \%$ of the costs, often tens of thousands of dollars, can be covered (Alameda County 2011; Environmental Defense Fund 2007). The district helps coordinate permits, acquire Safe Harbor Agreements that protect the ability to use the pond for livestock, and find mitigation and conservation easement opportunities.

A common comment of ranchers is that if society would just pay them directly to raise endangered species ranchers could make them plentiful. Cost shares and conservation banking can bring much needed funding to ranchers who can navigate the paperwork and bureaucracy, and who have an endangered or threatened species on their land that they can manage for and still maintain operations. As a rancher with a tiger salamander easement said at a meeting of the Central Coast Rangeland Coalition in 2011, 'These salamanders are the most valuable livestock I've ever raised'. In the USA, this is one of the forms of 'payment for ecosystem services' that is extant though seldom acknowledged as such. However, these incentives depend on recognition that grazing can be benign and even beneficial, while removing grazing can change the habitat in harmful ways. There is always 
an element of risk to a rancher when becoming involved in endangered species protection because of the large scale politics attached to federal and state legislation.

\section{The California Black Rail: interdependence and tradeoffs}

The California Black Rail (Laterallus jamaicensis cotuniculus) is a secretive bird that is listed by the state of California as threatened and, for a long time, was thought to remain only in limited coastal marsh areas. In 1994, it was found for the first time in small shallow wetlands scattered through the northeastern California Sierra Nevada foothills. These lands are mostly ranch lands interspersed with expanding patches of residential development. About $89 \%$ of its habitat in this region was found to be associated with irrigation ditches that provide water to ranches and farms, with $63 \%$ of the habitat on private lands (Richmond et al. 2010). Irrigation ditches and stock ponds that feed livestock watering facilities or irrigate pastures create wetlands where water seeps into the grasslands as does the runoff from irrigated pasture. It is clear that the fate of ranching and the species are intertwined.

Research suggests that grazing may need to be constrained in or excluded from these small natural and artificial wetlands (Richmond et al. 2010), especially during the breeding season and in sites that are not fed by irrigation water (Richmond et al., 2012). The Black Rail lives entirely within thick stands of herbaceous wetland plants and is found in very shallow water $(\leq 3 \mathrm{~cm})$. It will vacate sites that are grazed too intensively. Thus, while the relationship between the bird and the ranching landscape is clearly synergistic, there are potential tradeoffs between livestock grazing and bird use. For individual wetlands, removal of grazing has both long- and short-term results. It may prevent consumption of wetland plants needed to sustain the bird within a particular year, but exclusion of grazing over decades may also lead to vegetation change that can alter the habitat due to invasion of shrubs, vines, and other woody species into the wetland, creating a state three ecosystem. In one extreme case, in an effort to 'restore' the wetlands into conforming with a normative notion of wildlife habitat, one wildlife agency planted trees in some of the wetlands on government land. These are now reaching a size where they shade out the grasses and respire the water that forms the bird's habitat. On a field trip to see Black Rails, one of the well-meaning people who helped plant the trees commented, 'What were we thinking? Now we are going to have to go back in and cut those trees down'.

Researchers studying Rails find it a challenge to obtain the cooperation of landowners, yet they need landowner permission to enter private land for surveys. Landowners fear possible consequences from the Endangered Species Act even though the bird is not federally listed. The longer-term challenge is to help ranchers see the bird as more of an opportunity than a burden, the way some of the ranchers in the previous case now see the tiger salamander. Unfortunately, as is typical for agricultural operations in California, there are also conflicts among the many regulations and policy initiatives that affect natural resources on private lands. For example, in this area, there is a push to conserve water with local government programs encouraging cement lining of irrigation ditches and fixing 'leaky' irrigation systems. The outcome could be disastrous for the Rails.

One of the counties where the Rails are found is currently developing a Habitat Conservation Plan for the portion of the county that includes all the potential Rail habitat. Still undergoing review, the plan acknowledges the need for protection of large contiguous areas and corridors for protection of some species but does not mention the 
need to do anything to conserve ranching. While several of the endangered species described in the plan are observed to do better with livestock grazing, where the livestock are going to come from in the long term is not considered. Instead, the draft recommendation is that large areas of land be acquired and managed by the government to conserve wildlife. Even when convinced that livestock grazing is essential for maintaining species abundance, managers and planners often fail to consider the ranches or people that produce stock. As in many parts of the world, government and nongovernmental organizations hire 'professional land managers' or 'environmental consultants' that do not know the rancher's perspective, respect rancher knowledge, or understand the imperatives of the pastoralist operation. They may ask ranchers to graze for a month here or a month there at limited times, making an economic enterprise infeasible. As one rancher commented at a local symposium in 2001:

They don't realize that you cannot just put the cattle on a shelf when you don't need them...they have to go somewhere. Now I am spending money and contributing to carbon emissions by trucking my animals long distances from season to season, because government managers don't want them here in the summer. Is that green?

\section{Rare species and livestock grazing}

Over the last two decades, as grazing has been removed from more areas, examples of cases where removal of grazing has had the opposite of the intended effect, have accumulated (Barry 2011). These include endangered butterflies (Weiss 1999), Burrowing Owls (Nuzum 2005), insects (Dennis et al. 1997), kit fox (Balestreri 1981), kangaroo rats (Kelt et al. 2005; United States Department of the Interior Fish and Wildlife Service 1997), flowers (Barry 2011), and a host of rare flora and fauna associated with vernal pools (Marty 2005, Pyke and Marty 2005). In many cases, the reason grazing is a positive force is because grazing helps control the nonnative grasses that otherwise overwhelm many species or change habitat conditions in a state three ecosystem.

In addition to benefits in the pasture, at the landscape scale, pastoralism and wildlife conservation have considerable synergy. Pastoralists own much of California's best wildlife habitat and maintain it in a quasi-natural state for rangeland grazing. The imperatives of pastoralism mean large areas of land and livestock mobility, a pattern of land use that is compatible with many wildlife species. When ranchers sell their lands for development, that habitat is lost. When it goes into park status and grazing is removed, it converts to a new state, putting species at risk. Conservationists have become concerned, calling for the support of ranches as a means of conserving open land. Ranchers fear that this might lead to limits on their ability to sell their land when they need to, but they also see opportunities for marketing 'conservation easements' that provide cash payment to ranchers in exchange for giving up the right to develop the land. Nongovernmental entities that broker the sale of conservation easements, such as The Nature Conservancy and the California Rangeland Trust, report that there are more ranchers interested in selling an easement than there are funds to buy them.

Coming up against the norms of environmentalism and the discourse of restoration, the effort to conserve habitat by conserving ranches runs into at least two kinds of trouble related 
to scale. On the one hand, those interested in conserving ranches to conserve the landscape may want more restrictions on grazing in the pasture, perhaps increasing costs to the point where the ability of the rancher to earn an income is compromised. On the other hand, those demanding the grazing of pastures to maintain wildlife and plant habitat may fail to consider that this also requires conserving ranches as viable enterprises, including attendant mobility and year round grazing opportunities, as pastures persist only as part of ranches.

Although pastoralism had an important role in transporting and facilitating the spread of nonnatives in California, ironically, the success of the nonnatives now makes livestock grazing a part of their management. The ecosystem has been changed irrevocably along with the management options. The environment has been 'engineered' (Jones et al. 1994) by the people that have constructed ponds and ranches and by the livestock themselves. The role of livestock in maintaining biodiversity in Mediterranean ecosystems where grazing has been a land use for thousands of years is acknowledged (Perevolotsky and Seligman 1998), but finding this in a system that has been influenced by livestock for such a short time is unexpected and has both positive and negative consequences for pastoralists.

\section{The Southwestern desert: a legacy of change}

As in California, the rangelands of the southwestern USA evolved without livestock until the arrival of Spanish explorers. The region is in the Basin and Range Province characterized by isolated north-south trending mountain ranges separated by broad alluvial valleys with strong elevational and topographic gradients of temperature, precipitation, and vegetation (Figure 3). Grasses dominated the valleys above roughly $900 \mathrm{~m}$, grading into oak savannas, pinon-juniper woodlands, and coniferous forests in the mountains. Bimodal and highly variable precipitation, varied topography, and the biogeographic location of the region-at the interface of the Great Plains, Rocky Mountains, Sierra Madre Occidental,

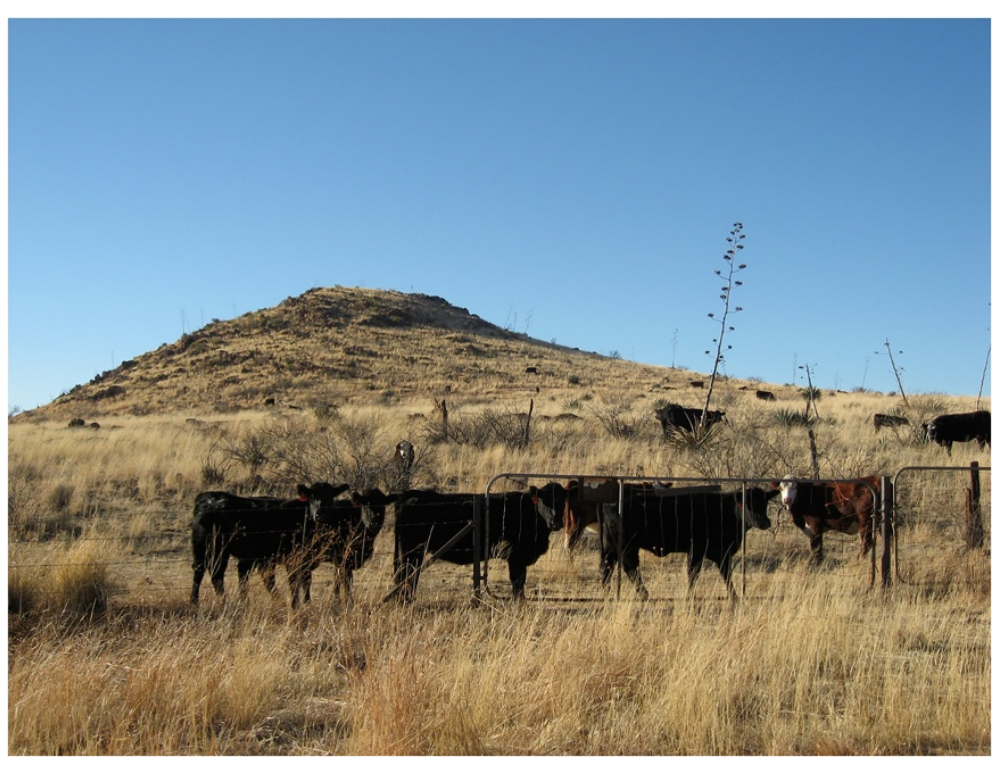

Figure 3 Cattle graze on the southwestern desert in Arizona. Mesquite shrubs are scattered through the grassland. 
and the Chihuahuan and Sonoran deserts-endowed the southwest with the highest known levels of biological diversity in the USA (Brown and Kodric-Brown 1996).

Unlike in California, however, the arrival of European settlers, livestock, and associated organisms did not quickly rearrange the southwest's native vegetation. Scholars believe that the first cattle entered the region with the expedition of Francisco Vasquez de Coronado in 1540-1542, and that some of these animals escaped and became feral, leaving descendents that were encountered by Anglo-American explorers and settlers in the 1800s. In New Mexico and Arizona, Native Americans acquired livestock from Spanish settlers and incorporated livestock husbandry into their cultures (Bailey 1980), but environmental historians have found no evidence that these cattle caused widespread or lasting impacts on the landscape (Bahre 1991).

Several factors probably contributed to this. Most importantly, the region's climate differed significantly from most of Europe such that newly arriving plants did not find suitable conditions for rapid establishment and spread. Additionally, both crop agriculture and pastoralism were constrained by limited surface water supplies, periodic droughts, and extreme temperatures, as well as prolonged resistance from the Apache Indians who tenaciously defended large parts of the region well into the 1870s. Moreover, the desert grasslands had evolved to withstand disturbance by native grazers and, especially, by fire. Bison were present in the areas closest to the Great Plains (present day New Mexico and western Texas) and probably ranged in limited numbers into what is now southeastern Arizona. Native perennial grasses such as blue grama (Bouteloua gracilis) and black grama (B. eriopoda) maintained their dominance over shrub species such as mesquite (Prosopis spp.) with the regular assistance of fire, set both by native peoples and by lightning, which is abundant at just the time of year when fires are most likely to spread (in early and mid-summer, after the long spring dry period). As best can be determined, fires recurred in the grasslands at intervals of 8-12 years, setting back shrubs and favoring grasses (Kaib et al. 1996).

Dramatic environmental change occurred beginning in the 1870s with the final conquest of the Apaches, the discovery of massive mineral deposits (especially silver and copper), the arrival of the railroad, and huge influxes of capital from the northeastern USA and Great Britain, much of it underwriting livestock imported from surrounding regions (Dobyns 1981, Bahre 1991). Wetter periods (often associated with El Nino years (Swetnam and Betancourt 1998)) produced bountiful forage and encouraged rapid growth in herd sizes which overwhelmed the grasslands during subsequent droughts. The period from 1880 to 1910 encompassed several of these climatic cycles, including severe droughts in 1891-1893 and 1898-1904, when vast areas were grazed bare of vegetation (Bahre and Shelton 1996, Sayre 1999). Heavy rainfall events resulted in arroyo formation throughout the region, permanently altering the hydrology of nearly every major valley (Cooke and Reeves 1976).

This history is profoundly important to issues of wildlife and pastoralism in the Southwest up to the present day, but not in obvious or straightforward ways. Wildlife populations were undoubtedly affected by the environmental changes of the late nineteenth century but with one partial exception, the Masked Bobwhite Quail (Sayre 2002), none were extirpated by grazing impacts. Large predators were subsequently hunted to regional extinction, including the jaguar, Mexican gray wolf and grizzly bear, and some important small mammals, such as the black-tailed prairie dog, were persecuted as pests and 
dramatically reduced in range and numbers (Oakes 2000). Hunting pressure and habitat changes also reduced populations of game species such as deer, pronghorn, and bighorn sheep. The impacts of regional environmental change on wildlife were otherwise indirect, incomplete, and of difficult attribution, particularly with regard to livestock.

What matters, instead, are the legacy effects of the cattle boom period both on the landscape and in relation to wildlife regulations, especially the Endangered Species Act. Human engineering of southwestern landscapes responded to the crisis in numerous ways, moderating the intensity of grazing impacts but also facilitating their areal expansion through the construction of artificial water sources (including wells, pipelines, and earthen tanks to capture run-off) and fences. In Arizona, a state typical of the region, $74 \%$ of the land is federally administered, and $14 \%$ is administered as state land. Policy reforms on government rangelands, implemented after 1905 for national forests, 1912 for state lands in Arizona and New Mexico, and 1934 for remaining public domain lands (now administered by the Bureau of Land Management), imposed controls on herd sizes which declined steadily during the twentieth century to less than $25 \%$ of peak levels in the 1890 s (Sayre 2002). Meanwhile, the landscape responded in ways that were unexpected and poorly understood at the time. Arroyo formation lowered water tables, desiccating former floodplains and converting marshes (known regionally as ciénegas) and grassy meadows of sacaton (Sporobolus wrightii) into woody corridors (of cottonwood and willow in wetter arroyo bottoms and mesquite forests on former floodplain terraces) (Turner et al. 2003). Miles of perennial surface flow were lost to higher run-off rates and groundwater depletion.

Most important for the region's rangelands as a whole was the interruption of the evolutionary fire regime, with widespread fires largely disappearing after 1893 (Swetnam et al. 1999). This was explicit government policy spearheaded by the Forest Service and applied throughout the region. Livestock grazing was probably even more important than direct fire suppression because it reduced standing fine fuel loads and, thereby, inhibited both ignition and spread across vast areas. Stocking rates varied much less than precipitation. In the Chihuahuan desert, annual rainfall is less than 50\% of the long-term average in one year out of two (Herbel and Gibbens 1996). Thus, grazing impacts were most severe during droughts-when fires would have been most likely, and when they had previously been common-effectively ensuring that fires ceased in grazed grassland sites. As artificial waters were installed, more and more of the landscape fell into this category. By the 1930s, shrubs had gotten the upper hand over grasses throughout the region. Because mesquites can withstand fire by resprouting from root crowns once they exceed $1 \mathrm{~cm}$ in diameter, even 10-20 years without fire could set woody encroachment in motion for decades to come, gradually reducing grass production and, in a positive feedback, inhibiting fire further (Sayre 2003).

As previously mentioned, both environmental policy and public perception in the USA reflect widespread belief in a singular 'natural' equilibrium state, enshrined in Clementsian ecological theory as the climax to which ecosystems will return if disturbances are removed. Southwestern desert grasslands have proved to be a prime counter-example, and much of the scientific work of discovering this and defining alternative ecological models has been based on research in the region (Westoby 1980). Woody encroachment has occurred even in sites where livestock were permanently removed in the first decades of the twentieth century, and by the 1940s, range scientists were developing mechanical (and later chemical) methods of combating mesquites and 
other shrubs, effectively abandoning the idea that stocking reductions alone could result in grassland restoration (Sayre 2010).

If restoration of original conditions does not happen naturally, however, this has not prevented the implementation of regulatory policies that tacitly presuppose the contrary. For as long as the Endangered Species Act has been in effect, the listing of species has been attended by calls for the reduction or elimination of livestock grazing on southwestern rangelands. Until recently, federal agencies, environmental NGOs, and many scientists adhered to a common model for endangered species conservation in the region: find the best habitat and protect it by removing human commercial activities which almost always includes livestock grazing. Examples abound, especially among birds (e.g., Masked Bobwhite Quail, Southwestern Willow Flycatcher, and Cactus Ferruginous Pygmy Owl) and fish (e.g., Gila topminnow, Gila chub, and Yaqui chub).

The conventional model is reinforced by legal bureaucratic procedures that obscure the historical and ecological dynamics described above. When a species is listed as threatened or endangered, the Fish and Wildlife Service is obligated to delineate its historical range based heavily on documentation of specimens collected and cataloged for taxonomic purposes. This area becomes the de facto baseline for evaluating present distribution and potential critical habitat regardless of whether the area is or could be viable habitat today. Similarly, listing involves specifying known threats to the species (or populations thereof), and livestock grazing is invariably included, if only because of the widespread impacts of the late nineteenth century and the subsequent changes entrained therefrom-regardless of whether current, actual livestock grazing is known to be causing harm. Given that livestock grazing has been widespread and ongoing in the region for well over a century, moreover, it would be reasonable to ask how a listed species could have persisted on grazed rangelands at all if it were fundamentally incompatible with livestock.

In other words, if a rare wildlife species is found on a ranch today, it would be just as logical to attribute a positive role to livestock grazing as a negative one if indeed it plays any role at all. In a few cases, similar to those described from California, this possibility has in fact been recognized and codified by the Fish and Wildlife Service. The Chiricahua leopard frog (Rana chiricahuensis), listed as threatened in 2002, has declined with the loss of natural perennial surface waters and the spread of predating bullfrogs. It persists primarily in refugia it has found in ranch stock tanks which provide perennial habitat discontinuous from bullfrog-invaded streams. The Fish and Wildlife Service, therefore, chose to exempt stock tank maintenance activities (such as removing accumulated sediment which is done with bulldozers) from the definition of take for the leopard frog (United States Department of the Interior Fish and Wildlife Service 2002). One Habitat Conservation Plan and three Safe Harbor Agreements are now in effect for various places in the Southwest to ensure that ranch-related activities do not run afoul of endangered species protections for the leopard frog (United States Department of the Interior Fish and Wildlife Service 2002).

More generally, there is growing recognition within the Fish and Wildlife Service and sectors of the environmental community at large that normal, ongoing ranching activities today are benign with respect to most listed species. When the Malpai Borderlands Group, a coalition of ranchers in extreme southeastern Arizona and southwestern New Mexico, conferred with Fish and Wildlife Service and other agency scientists to craft a 
Habitat Conservation Plan, for example, they reviewed the scientific literature for more than 50 rare species (including ones already listed and others that might become listed) and evaluated a suite of ranching practices (from livestock grazing to stock tank maintenance, fence and waterline construction, and prescribed and wild fire) in relation to each species. They could find only one scenario that might pose a serious risk of constituting take under the Act: if a large prescribed fire were followed by severe rainfall that resulted in sediment deposition sufficient to impact listed fish species downstream of the fire. They subsequently formalized a plan covering 19 species (nine of them listed under the ESA) and providing regulatory protection for various range and livestock management activities. Significantly, the plan does not cover livestock grazing in and of itself-that is, herbivory or the consumption of vegetation by livestock-because the probability of take for any covered species was judged to be too remote to justify its inclusion (Lehman 2007).

It is important to understand that this shift in perspective regarding pastoralism and wildlife in the southwestern USA has occurred against a larger backdrop of land use change that has recast ranching from a threat into a key ally for conservation. Although large areas of the region are undeveloped, uncultivated, and un-fragmented, private lands are a small part of the whole, and they are generally located where water and fertile soils are concentrated (Scott et al. 2001). With rapid economic and population growth after World War II, these private lands rose rapidly in market value, and by the end of the century, they were far more valuable as potential residential homesites than as sources of livestock forage (Theobald 2001; Hansen et al. 2002, 2005). As ranches were sold and converted for development, key wildlife habitat was lost in ways that were effectively permanent and greatly exceeded the harm done by livestock in recent decades (Theobald et al. 1997; Brown et al. 2005). Keeping ranches in business began to look like an important strategy for regional conservation of wildlife and open space, especially when compared to the high cost of buying land for public or private preserves.

In two key respects, however, the regulation of wildlife under the Endangered Species Act in the Southwest remains contradictory in ways that adversely affect pastoralism. First, the definition of take contains (or ignores) a contradiction between impacts to individual specimens and impacts to populations of a listed species. Second, what constitutes an action that can be restricted under the Act is ecologically contradictory once one recognizes the degree of long-term human engineering of the region's landscapes. The issue of fire serves to illustrate both contradictions.

More than a century of fire suppression has profoundly altered the Southwest's grasslands and forests, triggering woody encroachment in the former and allowing the buildup of extraordinary fuel loads in the latter. Neither change will undo itself 'naturally' by the removal of its historical causes: shrublands will persist even without livestock grazing, and dense forests will eventually burn at intensities that will result in nearly total tree mortality. The management activities needed to rectify these situations-mechanical removal of shrubs and trees, and/or prescribed fire-may well result in take of specimens and, therefore, must meet stringent standards under the Endangered Species Act. But the decision to do nothing, which does not count as an action and, therefore, cannot constitute take under the Act, may threaten listed populations either abruptly (when the inevitable but unpredictable wild fire burns through the overgrown forest) or through the slower, incremental process of grassland-to-shrubland conversion. These contradictions 
apply to other longstanding regional environmental problems, such as arroyo formation, as well.

The contradictions are most acute on federally owned lands because federal agencies must consult with the Fish and Wildlife Service whenever an action might jeopardize a listed species. Paradoxically, the Forest Service has never had to subject its policy of fire suppression to the process of Endangered Species Act consultation even though it has arguably been the single most important driver of environmental change in the Southwest (and elsewhere in the USA) and can be viewed as ecological engineering in its own right. By contrast, every 10 years, when a Forest Service grazing permit expires, renewal of the permit constitutes an action that must clear the scrutiny of the Act as part of the public consultation process. Given the historical longevity of grazing in the region, however, and the extent to which the landscape has been altered by human activities (for both better and worse), removing livestock might constitute a more dramatic ecological act than not doing so (Sayre 2005).

\section{Separating wildlife and livestock in the Intermountain West}

The Intermountain West is an arid region of North America lying between the Rocky Mountains to the east and the Cascades and Sierra Nevada to the west. Cattle ranching and sheep grazing are the most common activities on the uplands in this cold desert steppe (Figure 4), and it is mostly in government ownership with the Forest Service, Bureau of Land Management, and Department of Defense as the primary administrators. Irrigated lands near water are used for agriculture, including hay production, and are often in private ownership. In the southern zones of the region, the winters are short, and there is little precipitation. In the northern portions, the winters are cold and can have significant snow, with hot and dry summers. The vegetation ranges from sparse grasslands and sagebrush to other plants that are able to survive in desert or semidesert conditions in basin lands. Some higher elevation areas have isolated stands of pine, cedar, and aspen tree forests. Idaho is one of the states in this region, and 63\% of it is in government ownership (mostly federal), including

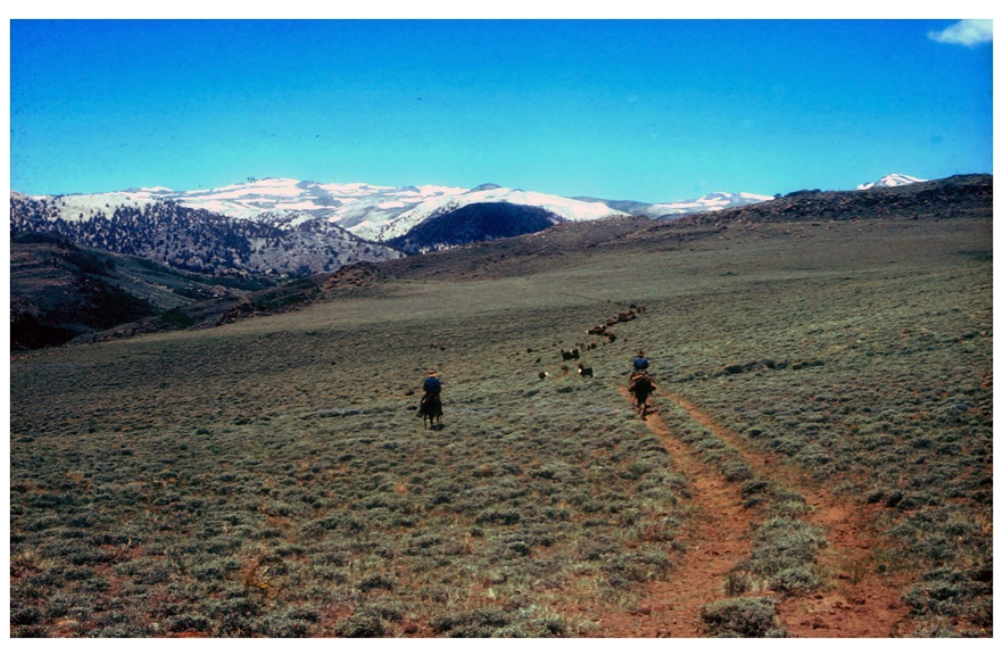

Figure 4 Livestock are moved into the mountains in summer in the Intermountain cold desert steppe. In the mountains, summer range may overlap with habitat for the bighorn sheep. 
the largest percentage of Forest Service lands as a percentage of total area within a single state. Bighorn sheep inhabit the montane parts of Intermountain rangelands as do ranchers and shepherds for summer feed for their stock often as part of a pattern of transhumance.

Agency management to maintain viable populations of wildlife species has become one of the most poignant issues affecting pastoralism and wildlife in the Intermountain West today. Often a function of appeals to regulations designed to implement agency management plans and/or revisions, agency officials now suffer barriers such as a 'culture of fear' from litigation and socio-political conflict associated with contemporary pastoralism and grazing (Knight and White 2009). This cultural and political context not only saddles managers' day-to-day activities but, in effect, presents a significant risk to ranching operations, many of whom became the default stewards of vast working landscapes, open rangelands, and ecological connectivity and services. The recent landmark case of separating domestic and bighorn sheep on the Payette National Forest in Idaho exemplifies the complexities of this trend. In the Payette, agency protocols reflect short-term temporal scales in the move toward separation of species as well as single species management rather than an understanding of the rangelands as a system of interactive effects.

\section{Species viability and wildlife separation}

The following recitals appear at the front end of the Idaho Department of Fish and Game (2008) interim policy to manage for separation between bighorn sheep and domestic sheep:

Whereas, bighorn sheep are native to Idaho and have been restored to some historic habitat in partnership with federal land management agencies, other state agencies and private organizations;

Whereas, bighorn sheep are historically, culturally and economically valuable to the citizens of the State of Idaho and Tribes;

Whereas, the domestic sheep industry is historically, culturally and economically valuable to the citizens of the State of Idaho;

Whereas, it is in the public interest to maintain and restore bighorn populations, where appropriate;

Whereas, it is in the public interest to maintain and restore access to state and federal land for grazing by domestic sheep, where appropriate;...

Die-offs from various respiratory-related diseases have chronically affected bighorn sheep populations in the western USA since the mid-1800s (Schommer and Woolever 2008). While bighorn sheep die-offs have occurred in every western state (Toweill and Geist 1999), recent conflicts in Intermountain states over the origins of disease effects on bighorn populations have erupted within the contexts of litigation over public lands grazing, Endangered Species Act dynamics, and the restoration discourse all noted above. In the past 5 years, under these intensifying management and policy conditions, federal and state land management agencies have now developed strategic policies and management protocols that will require species separation as a means to ensure minimum viable populations for given areas. Although not currently constrained as a listed species within the Endangered Species Act, the Rocky Mountain subspecies of bighorn sheep holds its status as an iconic and symbolic 
wildlife species caught within the conflict over land use and management. The implications run deep.

A strong scientific debate continues as to whether populations of domestic sheep (Ovis aries) and goats (Capra hircus) make bighorn sheep (Ovis Canadensis) more susceptible to respiratory diseases and pneumonia. Scientific literature exists along the continuum of the debate, e.g., both disease transmission (Foreyt et al. 1994; Onderka et al. 1988) and the reasons for bighorns' apparent greater susceptibility to Pasteurella haemolytica (now equivalent to Mannheimia haemolytica) remain unknown and unproven (Dassanayake et al. 2011; Miller et al. 2008). Thus, while most involved in studying and managing the issue readily admit that disease transmission can occur, many also recognize that a particular bacterium is not the cause of all bighorn die-offs. In fact, a variety of factors other than just disease affect and compound herd health (nutrition, weather, density, predation, management, and stress). Habitat management for bighorn, like many other species, can vary by water availability, noxious weed encroachment, recreation and other disturbance, subspecies migration and transplantation, and landscape connectivity (Idaho Department of Fish and Game 2010). Ongoing research has also continued to test whether vaccinations are an option to avoid the management extremes of separation.

Further, Intermountain rangelands have been severely affected by the invasion of a nonnative annual grass, cheatgrass (Bromus tectorum). Cheatgrass, introduced in the nineteenth century in wheat seeds, is a powerful agent of ecosystem engineering. Evidence is strong that it can invade the sagebrush grasslands without human-caused disturbance (Goodrich and Gale 1999), and once it has invaded, it increases the fire frequency by providing a continuous layer of fine fuel. This, in turn, leads to the extirpation of shrubs and herbaceous species that are part of the bighorn diet (Wagner and Peek 2006). The grass itself provides some nutritious green forage for a few months before turning brown and dropping most of its nutritional value for most of the year. The diversity and quality of the diet of grazing animals is severely reduced once the shift to a cheatgrass-dominated state occurs. This has been identified as a potential stressor on bighorn populations (Wagner and Peek 2006) that might contribute to lowered disease resistance and higher mortality from a variety of sources. As in the California case, though livestock have contributed to the spread of the plant, livestock grazing can also be used to reduce the fine fuels and help prevent the cheatgrass-fueled fires that convert the vegetation to cheatgrass dominance. In line with the restoration discourse already described, politically popular approaches to controlling cheatgrass call for seedings with native grasses and shrubs. Unfortunately, the non-equilibrium dynamics of these arid rangelands leads to a high failure rate for such seedings, and cheatgrass, as noted above, invades even intact native grasslands as most native species are not competitive with it. On the other hand, a nonnative perennial grass species, crested wheatgrass (Agropyron cristatum), can resist cheatgrass invasion but is politically unpopular because it is nonnative and cannot be considered a valid part of restoration as envisioned in restoration discourse.

For the wool and lamb industry, pastoral uses of the same Intermountain rangeland landscapes traditionally inhabited by bighorn sheep began in the 1840s with domestic sheep crossing southern Idaho along the Oregon Trail. In 1890, the domestic sheep population had grown to over 600,000 and close to three million at the end of World War I (Hart 2009). Scottish and Basque family heritage have comprised much of the multi- 
generational industry sustained today in Idaho, with total herd numbers reduced to between 220,000 and 235,000 (National Agricultural Statistics Service 2011). Despite the substantive change in domestic sheep production in Idaho, the industry has experienced continued demand for lamb and wool, especially recently in more globalized markets.

Nearly half of all domestic sheep produced in the USA spend time grazing on public land allotments. Although $80 \%$ of sheep producers are east of the Mississippi River, a full $80 \%$ of the sheep exist within operations west of the Mississippi River, making the public-private lands structure of many larger operations more striking with regard to overall industry production. To put this scale in perspective though, in Idaho, the Forest Service manages roughly 22 million acres including about 5.3 million acres of bighorn habitat. Domestic sheep allotments overlap a small percentage of the bighorn habitat, confined to 138,000 acres; however, this overlap constitutes critical summer forage range within the pastoral migration patterns. Culturally and economically, the bighorn represents multiple values in the state of Idaho for wildlife enthusiasts and hunters, the latter of which generate significant revenue for the state management agency through hunting license and tag sales. The domestic sheep industry also sustains a long-standing and renowned annual 'trailing of the sheep' to celebrate the traditional migration of sheep bands to winter range elevations coordinated with a fall cultural and heritage festival. Currently, almost all sheepherders in Idaho are native Peruvians as willing and skilled American sheepherders have disappeared from the Intermountain labor force.

\section{Turning point of the 'Payette Principles'}

In 2003, Idaho's Payette National Forest revised its management plan. Concerns about whether or not it allowed adequate viability of bighorn populations led to an appeal eventually upheld by the chief of the Forest Service in 2005. The following year, the Forest Service produced a risk analysis report to address bighorn viability on the forest and convened a panel of 11 scientific experts resulting in a consensus of the 'Payette Principles' (Payette National Forest Science Panel 2006). The principles are broad and suggest a great deal of uncertainty about disease transmission between the wildlife and livestock but perhaps more importantly also planted the seed for 'separation policy' as a means to address the viability mandates. Regulations regarding implementation have continued to evolve and remain controversial over the last 30 years, including the definition and use of what constitutes 'viable populations' for species the Forest Service is required to sustain.

The emergence of new demands on the 'Minimum Viable Population rule' eventually led to significant management change within the Payette National Forest. In 2010, the Forest Service issued a Record of Decision to cancel 70\% of the grazing allotments on the Payette National Forest in order to achieve separation of bighorns and domestic sheep. Due to the inability to prove that disease transmission would not occur if the Forest Service maintained the leases, the agency could not guarantee a minimum viable population for the bighorn and, thus, began canceling grazing permits for allotments in the Payette with the plan to phase in additional cancellations. Ambiguity remains as to whether all affected allotments constitute habitat and range for bighorns. The agency has also required additional on-the-ground 
management strategies (e.g., daily global positioning system records of each domestic herd).

Because the Payette National Forest lies within the state boundaries of Idaho, and bighorn are managed by the Idaho Department of Fish and Game, the state also 'acted' amidst the turmoil of the management plan debate and prior to the 2010 Forest Service decision. Idaho governor Butch Otter convened a collaborative task force, including scientists, industry representatives, wildlife advocates, political representatives, tribal representatives, and agency officials. The diverse group originally agreed to the following mission statement: To maintain and restore bighorn sheep populations without causing undue economic hardship on either the domestic sheep industry in Idaho or individual Idaho sheep producers (Idaho Department of Fish and Game 2010, page 2). Issues of federalism crept into the States' 2009 legislative session, however, with multiple bills proposed to address the issue:

- SB1175 proposed the state kill all bighorn sheep that came into contact with domestic sheep was passed by both the State Senate and House and, then, vetoed by Governor Otter; subsequently,

- SB1232a proposed the Idaho Department of Fish and Game, in collaboration with the woolgrowers, develop best management practices for domestic sheep operations on the Payette National Forest with the intent of separation but that would give assurances to producers as well as Forest Service personnel about maintaining viable populations of bighorns.

SB1232a only required voluntary participation by sheep producers (eventually 18 of 21 agreements were made for the Payette) and was signed into law but presented challenges in that it was not clear whether the state of Idaho or the Forest Service had ultimate control over the outcomes for producers with respect to management and policy for wildlife-livestock interactions. The conflict intensified such that several participating environmental groups, along with the Nez Perce Indian Tribe, withdrew from the state-level advisory group attempting to provide collaborative recommendations. While both the federal- and state-level actions represent macro-strategies toward engineering the landscape, the recent actions illustrate the variability in approaches at the science-policy interface affecting vast areas of rangelands in the West. The Payette case also demonstrates that 'disturbance' with effect(s) to the landscape can occur through the courts, routine and required public consultation processes, and the rhetoric that accompanies management debates. Yet, rarely are such social disturbances accounted for in agency policy decision making.

\section{Restoration and precedence}

While no definitive agreement exists, estimated bighorn sheep populations were higher historically, suggesting an overall decline despite habitat and range having remained the same. In some areas where bighorn have been transplanted, herds have re-established with varying success. Most states do not re-establish bighorn proximate to domestic sheep allotments (Schommer and Woolever 2008); however, in 1997, after a series of transplanted populations were reintroduced to the Hells Canyon region, the Forest Service, 
Idaho Department of Fish and Game, and the Hells Canyon Bighorn Sheep Restoration Committee made an agreement with producers grazing in Hells Canyon that stated 'the potential risk, if any, of disease transmission and loss of bighorn sheep when the same invade domestic livestock or sheep operations is accepted' (O'Laughlin and Cook 2010).

No agreed to level of viable populations (minimum, or not) exists among the various stakeholders for situations like the bighorn/domestic sheep conflict. Although some have recognized resource management as a social problem for decades (Schroeder, 1977), the volatility of the conflict and strategies now used to affect and influence management and agency actions charge the overall management context with a type of dilemma for which many resource managers remain untrained. Social scientists might point out that the situation reveals that at least some stakeholders have vacated the social contract required for resource management to translate to environmental sustainability, stewardship, and ecological integrity. Some argue that paradoxically, the way environmental laws are 'used' to litigate against activities such as grazing in today's pastoral landscapes not only miss the mark of the original laws' intents but also, in some cases, could prevent the very environmental benefits the laws have as their core objectives (Nie 2008). The lack of a social license of cooperation, so to speak, that would bind stakeholders together (friends and foes alike) indicates the landscape, rural communities, and many of the resources that sectors of the population take for granted will continue to remain at risk, perhaps increasingly so. At least at the intersection of public lands and wildlife-livestock interactions, a 'congress' is needed to reinvigorate a spirit of cooperation to enable more sustainable change.

The pattern of far-reaching agency decisions to implement new policies such as with the Payette National Forest's Record of Decision for the bighorn sheep is also at risk of having ripple effects. In Idaho, although not mandated to do so, the Bureau of Land Management has already mapped 30-mile 'circles' around known bighorn sheep populations on lands it manages with the intent to eliminate all domestic sheep and goats in those ranges. Given Idaho's landscape and very urban population in a still very rural landscape, this will not only further affect domestic commercial sheep producers but also more mundane domestic contexts, such as families and children in farm youth programs learning pastoral skills and animal husbandry with livestock. More far reaching, the precedents set by the Payette decision could also 'jump' to begin to affect other species involved in other wildlife-livestock interactions in other regions (e.g., bison and cattle in Montana). These decisions may also have profound long term effects on the landscape by removing livestock as a potential management tool in attempting to stabilize the state change the rangelands are undergoing as a result of cheatgrass invasion. A failure to prevent this change is a serious long-term threat to the bighorn. In the Payette case, policy did not emerge absent from biological assessment but uses separation as a tool to articulate a biological stance within the working landscape.

\section{Conclusions}

Ranchers in the USA can act as crucial agents for wildlife conservation. Yet, in the discourse of wildlife conservation and restoration, they are persistently tagged as suspects 
in a narrative of environmental degradation. Regulations and policies often institutionalize this positioning, reflected in a story told by a rancher to students on a field trip in 2009:

\section{The wildlife biologist brought what looked like a shoebox filled with tiger salamanders out to my ranch for relocation. Her family was from India, she was educated in the city, and she had never been on anything like my ranch before. I drove her out to the pond and she took the salamanders out and they seemed happy to find themselves at the pond. We had to be careful-since I am not an approved wildlife technician, I am not allowed to touch them.}

Wildlife policy and a shift to a greater emphasis on biodiversity have had both positive and negative impacts on pastoralists. Where pastoralists own the habitat, regulations are a burden, but offering incentives can make having a rare species an opportunity instead of a risk. However, these incentives are not supported unless the benefits of maintaining grazing are recognized. Even so, the relationship between grazing as a local process and the need to maintain enterprises, communities, and landscape configurations is seldom appreciated. In the mixed ownerships of the southwest, alliances linking public and private lands have helped to stabilize land tenure and maintain habitat. Yet, wildlife and environmental policies are ill-equipped to resolve contradictions between conservation of individuals versus populations, or fire suppression and grazing removal as inactions that require no review versus grazing and burning as actions that require regulation and control. In the Intermountain West, where the majority of range is in federal management, removal of stock to enhance wildlife is not uncommon even though knowledge of wildlife-livestock interactions remains limited. The impacts of cessation of grazing on other species or of the loss of ranching enterprises on long-term conservation of un-fragmented rangelands are not considered.

Throughout the western USA, pastoralism-wildlife interactions are taking place in a changed and changing environment that can, in some cases, be understood as ecosystem engineering. The long-term change scenarios posited by Perevolotsky and Seligman (1998) for the Mediterranean Basin offer potential insight here. They suggest that the introduction of livestock grazing leads to a state change in ecosystems that eventually 'stabilizes' around a new set of state characteristics that are maintained by grazing, but not reversed by a removal of grazing. In fact, livestock removal can lead to another state change and a reduction in biodiversity. To some degree, the three cases presented here might fit this model, though the relative time span in the USA is quite short. However, what is clear in all the cases is that a focus on 'restoration' is unrealistic, and the failure to consider removal of livestock grazing as an ecologically potent action may in fact lead to further and more unfortunate ecosystem change. Absent adequate ecological information, the assumptions of innate conflict between livestock and wildlife, and that cessation of grazing is not an action, as well as the norms of a politically popular yet ecologically unsupportable discourse of restoration fill in the gaps. It is unfortunate that the available site-specific ecological information is most often quite limited.

Adaptive management is now the go to solution for situations where management takes place in a setting of 'ecological uncertainty'. It is clear that the adaptive management process can help improve the scientific information for a site, and that it 
encourages the flexible and responsive management that changing and non-equilibrial rangelands demand. Worth investigation is how adaptive management can and cannot work to help overcome the assumptions and norms that cloud management decisions and that obscure the linkages across local to landscape scales.

Pastoralism is in decline in the USA. As we learn more about the roles of ranching and grazing in creating and maintaining habitat at local and landscape scales, it behooves us to be concerned that the 'supply' of pastoralists is in danger (Brunson and Huntsinger 2008). Once removed, it may be that returning grazing to an ecosystem is impossible or prohibitive. Removing grazing from government lands may result in a permanent loss of valuable range and habitat, as ranches are sold and lands are developed as part of a westwide expansion of second homes and residential development (Sulak and Huntsinger 2007). Maintaining grazing on government lands without consideration of planning and protection for private lands may leave ranchers literally without a 'home'.

In all cases, the existence of bureaucratic systems of regulation and enforcement is perplexing to pastoralists. A common observation is that the government does things the most expensive way possible. Another is that ranchers are being punished for historically maintaining wildlife habitat as having that wildlife on public or private lands winds up reducing access and increasing costs. Not only is this a confusing message to send to food producers but, as landscape managers affecting ecological services for society as a whole, reduced access and increased cost signal the wrong incentives to them as stewards. For ranchers, an innate enjoyment of the environment and nature extends to wildlife, and pastoralists have shown themselves to be ready to steward rare species. Of the diverse groups attempting to conserve the landscape, many are increasingly seeing the multi-scale benefits-landscape and local-of pastoral systems despite institutional and legal barriers. These linkages must be fostered and maintained if extensive rangeland grazing is to persist in the USA.

Competing interests

The authors declare that they have no competing interests.

Authors' contributions

LH conceived of and led the paper, drafted the introduction, background, and conclusions, and wrote the first case study. NS contributed to the introduction, background, and conclusions, and wrote the second case study. JW wrote the third case study. All authors read and approved the final manuscript.

Author details

'Department of Environmental Science, Policy, and Management, University of California, 130 Mulford Hall, Berkeley, CA 94720, USA. ²Department of Geography, University of California, 507 McCone Hall, Berkeley, CA 94720, USA.

${ }^{3}$ Department of Agricultural Economics \& Rural Sociology, University of Idaho, Moscow, ID 83844, USA.

Received: 4 November 2011 Accepted: 27 February 2012

Published: 28 September 2012

References

Alameda County. 2011. Wildlife friendly ponds program. http://www.acrcd.org/ForFarmersRanchers/ WildlifeFriendlyPondsProgram. Accessed 30 October 2011.

Bahre, Conrad J. 1991. A Legacy of change: Historic human impact on vegetation in the Arizona borderlands. Tucson: University of Arizona Press.

Bahre, Conrad J, and Marylyn L Shelton. 1996. Rangeland destruction: Cattle and drought in southeastern Arizona at the turn of the century. Journal of the Southwest 38: 1-22.

Bailey, Lynn R 1980. If you take my sheep: The evolution and conflicts of Navajo pastoralism, 1630-1868. Pasadena: Westernlore Publications.

Balestreri, AN 1981. Status of the San Joaquin kit fox at Camp Roberts, California. Unpubl. Report, US Department Army, Environmental, and Natural Resources Office. San Luis Obispo: California Polytechnic State University.

Bartolome, James W, and Randall D Jackson. 2007. Grazing ecology of California grasslands. In Ecology and management of California grasslands, ed. Corbin Jeffrey, Stromberg Mark, and Carla M. D'Antonio, 197-206, Berkeley: UC Press. 
Barry, Sheila J. 2011. Current findings on grazing impacts: California's special status species benefit from grazing. California Cattlemen's Association Magazine. June 18-20. http://www.carangeland.org/images/11-06_CCA_Mag__Current_Findings_on_Grazing_Impacts.pdf. Accessed 11 March 2012.

Behnke, Roy H, lan Scoones, and Carol Kerven. 1993. Range ecology at disequilibrium: New models of natural variability and pastoral adaptation in African savannas. London: Overseas Development Institute.

Blench, Roger. 2001. You can't go home again: Pastoralists in the new millennium. Animal Production and Health Paper. Rome: Food and Agriculture Organization. http://www.odi.org.uk/resources/docs/6329.pdf. Accessed 30 October 2011.

Brown, Daniel G, Kenneth M Johnson, Thomas R Loveland, and David M Theobald. 2005. Rural land-use trends in the coterminous United States, 1950-2000. Ecological Applications 15: 1851-1863.

Brown, James H, and Astrid Kodric-Brown. 1996. Biodiversity on the borderlands. Natural History 105: 58-61.

Brunson, Mark, and Lynn Huntsinger. 2008. Can old ranchers save the new west? Synthesis paper. Journal of Range Ecology and Management 61: 137-147.

Cooke, Ronald U, and Richard W Reeves. 1976. Arroyos and environmental change in the American southwest. Oxford: Clarendon.

California Rangeland Trust. 2011. About the California rangeland trust. http://www.rangelandtrust.org/about_us.php. Accessed 31 October 2011.

Dassanayake, Rohana P, Paulraj K Paulraj Jr, Don P Knowles, William C Davis, William J Foreyt, and Subramaniam Srikumaran. 2011. Co-expression of ovine LPS receptor CD14 with Mannheimia haemolytica leukotoxin receptor LFA-1 or Mac-1 does not enhance leukotoxin-induced cytotoxicity. Veterinary Immunology and Immunopathology 14(1-2): 84-91.

Dennis, Peter, Mark R Young, Clarence L Howard, and lain J Gordon. 1997. The response of epigeal beetles (Col. Carabidae, Staphylinidae) to varied grazing regimes on upland Nardus stricta grasslands. Journal of Applied Ecology 34: 433-443.

DiDonato, Joseph. 2007. Endangered amphibian research within grazed grasslands. In Keeping landscapes working: A University California Cooperative Extension Newsletter for Rangeland Managers. Winter: 4-6. http://cesantaclara. ucanr.edu/news_719/Keeping_Landscapes_Working. Accessed 5 October 2007.

Dobson, Andrew P, Jon P Rodriguez, Mark W Roberts, and David S Wilcove. 1997. Geographic distribution of endangered species in the United States. Science 275: 550.

Dobyns, Henry F. 1981. From fire to flood: Historic human destruction of Sonoran desert riverine oases. Anthropological Papers No. 20. Socorro, NM, USA: Ballena Press.

Environmental Defense Fund. 2007. Alameda rancher and wildlife-friendly program restores ponds and helps rare animals. Center for conservation incentives October 10. http://www.edforg/search/google_cse_adv/alameda\% 20rancher. Accessed 30 October 2011.

Ferranto, Shasta, Lynn Huntsinger, Bill Stewart, and Maggi Kelly. 2012. Consider the source: The impact of media and authority in outreach to California's forest and rangeland owners. Journal of Environmental Management 97: 131-140.

Ferranto, Shasta, Lynn Huntsinger, Christy Getz, Gary Nakamura, William Stewart, Sabrina Drill, Yana Valachovic, Michael DeLasaux, and Maggi Kelly. 2011. Forest and rangeland owners value land for natural amenities and as financial investment. California Agriculture 65(4): 185-191.

Foreyt, William J, Kurt P Kurt, and Rick W Kasten. 1994. Fatal pneumonia following inoculation of healthy bighorn sheep with Pasteurella haemolytica from healthy domestic sheep. Journal of Wildlife Diseases 30(2): 137-145.

Goodrich, Sherel and Natalie Gale. 1999. Cheatgrass frequency at two relic sites within the pinyon-juniper belt of Red Canyon. United States Department of Agricluture Forest Service Proceedings. RMRS-P-9. In Monsen, Stephen B., Stevens, Richard, comps. 1999. Proceedings: ecology and management of pinyon-juniper communities within the Interior West; 1997 September 15-18; Provo, UT. Proc. RMRS-P-9. Ogden, UT: U.S. Department of Agriculture, Forest Service, Rocky Mountain Research Station, 69-71. http://www.fs.fed.us/rm/pubs/rmrs_p009/rmrs_p009_069_071.pdf. Accessed 26 December 2011.

Gosnell, Hannah, and William R Travis. 2005. Ranchland ownership dynamics in the Rocky Mountain West. Rangeland Ecology \& Management 58(2): 191-198.

Hansen, Andrew J, Ray Rasker, Bruce Maxwell, Jay J Rotella, Jerry D Johnson, Andrea Wright Parmenter, Ute Langner, Warren B Cohen, Rick L Lawrence, and Matthew PV Kraska. 2002. Ecological causes and consequences of demographic change in the New West. BioScience 52: 151-162.

Hansen, Andrew J, Richard L Knight, John M Marzluff, Scott Powell, Kathryn Brown, and Patricia H Gude. 2005. Effects of exurban development on biodiversity: patterns, mechanisms, and research needs. Ecological Applications 15: 18931905.

Hart, Arthur A. 2009. Idaho's rangelands: A history. Caldwell: Caxton Printers.

Heady, Harold F. 1958. Vegetational changes in the California annual type. Ecology 39(3): 402-416.

Heady, Harold F. 1977. Valley grassland. In Terrestrial vegetation of California, ed. M.G. Barbour and J. Major, 491-514. Sacramento: California Native Plant Society.

Herbel, Carlton H, and Robert P Gibbens. 1996. Post-drought vegetation dynamics on arid rangelands of southern New Mexico. NM, USA: Agricultural Experiment Station Bulletin, College of Home Economics, New Mexico State University.

Huntsinger, Lynn, James W James, and Carla M D'Antonio. 2007. Grazing management of California grasslands. In California grasslands: Ecology and management, ed. Jeffrey Corbin, Mark Stromberg, and Carla M. D'Antonio, 233-253. Berkeley: University of California Press.

Huntsinger, Lynn, Larry C Larry, and Adriana Sulak. 2010. Transhumance and pastoralist resilience in the western United States. Pastoralism: Research, Policy, and Practice 1(1): 1-15.

Idaho Department of Fish and Game. 2008. Interim strategy for managing separation between bighorn sheep and domestic sheep in Idaho. Boise, ID, USA. http://fishandgame.idaho.gov/public/wildlife/planBighornDomesticSheep. pdf. Accessed 11 March 2012.

Idaho Department of Fish and Game. 2010. Idaho bighorn sheep management plan. Bighorn Sheep/Domestic Sheep Advisory Group: Recommendations and final report. Idaho Department of Fish and Game and Idaho Department 
of Agriculture. Boise, ID, USA. to the Idaho Bighorn/Domestic Sheep Advisory Group. Boise, ID. http://fishandgame. idaho.gov/public/wildlife/planBighorn.pdf. Accessed 11 March 2012.

Jones, Clive G, John H Lawton, and Moshe Shachak. 1994. Organisms as ecosystem engineers. Oikos 69(3): 373-386.

Kaib, Mark, Christopher H Baisan, Henri D Grissino-Mayer, and Thomas W Swetnam. 1996. Fire history in the gallery pine-oak forests and adjacent grasslands of the Chiricahua Mountains of Arizona. In Effects of fire on Madrean Province ecosystems: A symposium proceedings, eds. Peter F. Ffolliott et al. USDA Forest Service General Technical Report RM-GTR-289. Fort Collins: Rocky Mountain Forest and Range Experiment Station: 253-264.

Kelt, Douglas A, Eddy S Konno, and James A Wilson. 2005. Habitat management for the endangered Stephens' kangaroo rat: The effect of mowing and grazing. Journal of Wildlife Management 69(1): 424-429.

Knight, Rick L, and Courtney White. 2009. Conservation for a New Generation: Redefining Natural Resource Management. Washington: Island Press.

Kreuter, Urs P, Malini V Malini, Douglas Jackson-Smith, JRichard Conner, and Janis E Johnston. 2006. Property rights orientations and rangeland management objectives: Texas, Utah, and Colorado. Rangeland Ecology \& Management 59(6): 632-639.

Lee, Henry K 2001. Probation given for relocating endangered frogs/Consultant also fined $\$ 10,000$. San Francisco Chronicle. http://articles.sfgate.com/2001-02-23/news/17586700_1_frogs-calaveras-county-wetlands-society. Accessed 29 October 2011.

Lehman, William. 2007. Malpai Borderlands Habitat Conservation Plan. AESO/SE 22410-2006-F-0408. http://www.fws. gov/southwest/es/arizona/HCPs.htm. Accessed 11 March 2012.

Liffmann, Robin J, Lynn Huntsinger, and Larry C. Forero. 2000. To ranch or not to ranch: Home on the urban range? Journal of Range Management 53(4): 362-370.

Lueck, Dean. 2002. The extermination and conservation of the American bison. The Journal of Legal Studies 31(2): S609-S652.

Lueck, Dean, and Jeffrey A Michael. 2003. Preemptive habitat destruction under the Endangered Species Act. Journal of Law and Economics 46(1): 27-60.

Maestas, Jeremy D, Richard L Knight, and Wendell C Gilgert. 2003. Biodiversity across a rural land-use gradient. Conservation Biology 17(5): 1425-1434.

Marty, Jaymee T. 2005. Effects of cattle grazing on diversity in ephemeral wetlands. Conservation Biology 19(5): 1626-1632.

Miller, Mike W, Don P Knowles, and Marie S Bulgin. 2008. Pasteurellosis transmission risks between domestic and wild sheep. Council for Agricultural Science and Technology Commentary QTA2008-1. Council for Agricultural Science and Technology: Ames, IA, USA: 8.

National Agricultural Statistics Service. 2011. Sheep and goats. http://usda.mannlib.cornell.edu/MannUsda/ viewDocumentInfo.do?documentID=1145. Accessed 30 October 2011.

Niamir-Fuller, Maryam. 1998. The resilience of pastoral herding in Sahelian Africa. In Linking social and ecological systems, ed. Fikret Berkes and Carl Folke, 250-284. Cambridge: Cambridge University Press.

Nie, Martin. 2008. The governance of western public lands: mapping its present \& future. Lawrence: University Press of Kansas.

Nuzum, Robert C. 2005. Report: Using livestock grazing as a resource management tool in California. Concord, CA, USA: Contra Costa Water District report. www.ccwater.com/files/LivestockGrazingFinal72005.pdf. Accessed 9 August 2006.

Oakes, Claudia Lea. 2000. History and consequence of keystone mammal eradication in the desert grasslands: The Arizona black-tailed prairie dog (Cynomys ludovicianus arizonensis). PhD dissertation, University of Texas. Austin, TX, USA: University of Texas.

O'Laughlin, Jay and Philip S Cook. 2010. Bighorn sheep and domestic sheep: Current situation in Idaho. Report No. 30. Policy Analysis Group. Moscow: College of Natural Resources, University of Idaho.

Onderka, Detlef K, Shirley A Rawluk, and William D Wishart. 1988. Susceptibility of Rocky Mountain bighorn sheep and domestic sheep to pneumonia induced by bighorn and domestic livestock strains of Pasteurella haemolytica. Canadian Journal of Veterinary Research 52: 439-444.

Payette National Forest Science Panel. 2006. Summary of the science panel discussion. US Geological Survey/Bureau of Reclamation Office, Boise, ID. http://www.fs.usda.gov/Internet/FSE_DOCUMENTS/fsm9_033215.pdf. Accessed 28 October 2011.

Perevolotsky, Avi, and No'am Seligman. 1998. Role of grazing in Mediterranean rangeland ecosystems-Inversion of a paradigm. BioScience 48(12): 1007-1017.

Pyke, Christoper R, and Jaymee T Marty. 2005. Cattle grazing mediates climate change impacts on ephemeral wetlands. Conservation Biology 19(5): 1619-1625.

Richmond, Orien MW, Jerry Tecklin and Steve Beissinger. 2012. Impact of cattle grazing on the occupancy of a cryptic, threatened, rail. Ecological Applications 22: 1655-16643.

Richmond, Orien MW, Stephanie K Chen, Benjamin B Risk, Jerry Tecklin, and Steven Beissinger. 2010. California Black Rails depend on irrigation-fed wetlands in the Sierra Nevada foothills. California Agriculture 64(2): 85-93.

Rowe, Helen I, Tom E Bartlett, and Louis E Swanson Jr 2001. Ranching motivations in two Colorado counties. Journal of Range Management 54(4): 314-321.

Sayre, Nathan F. 1999. The cattle boom in southern Arizona: Towards a critical political ecology. Journal of the Southwest 41(2): 239-271.

Sayre, Nathan F. 2002. Ranching, endangered species, and urbanization in the southwest: Species of capital. Tucson: University of Arizona Press.

Sayre, Nathan F. 2003. Recognizing history in range ecology: 100 years of science and management on the Santa Rita Experimental Range. In Santa Rita Experimental Range: 100 years (1903-2003) of accomplishments and contributions, eds. Mitchel P. McClaran, Peter F. Ffolliott and Carleton B. Edminster. USDA Forest Service Proceedings RMRS-P-30, U.S. Department of Agriculture, Forest Service, Rocky Mountain Research Station, Ogden, UT, USA, 30 October-1 November 2003. 1-15.

Sayre, Nathan F. 2005. Interacting effects of landownership, land use, and endangered species on conservation of southwestern US rangelands. Conservation Biology 19(3): 783-792.

Sayre, Nathan F. 2010. Climax and 'original capacity': The science and aesthetics of ecological restoration in the southwestern USA. Ecological Restoration 28: 23-31. 
Schommer, Timothy J and Woolever, Melanie M. 2008. A Review of disease related conflicts between domestic sheep and goats and bighorn sheep. United States Department of Agriculture Forest Service, Rocky Mountain Research Station: General Technical Report RMRS-GTR-209. Fort Collins, CO, USA.

Schroeder, William. 1977. Management by Court Decree. Miscellaneous Publication \#4, College of Forestry, Range, and Wildlife Sciences, University of Idaho, Moscow, ID, USA.

Scott, Thomas, Richard Standiford, and Nanette Pratini. 1995. Private landowners critical to saving California biodiversity. California Agriculture 49: 50-57.

Scott, JMichael, Frank W Davis, RGavin McGhie, RGerald Wright, Craig Grover, and John Estes. 2001. Nature reserves: Do they capture the full range of America's biological diversity? Ecological Applications 11: 999-1007.

Sulak, Adriana, and Lynn Huntsinger. 2007. Public lands grazing in California: Untapped conservation potential for private lands? Rangelands 23(3): 9-13.

Swetnam, Thomas W, and Julio L Betancourt. 1998. Mesoscale disturbance and ecological response to decadal climatic variability in the American southwest. Journal of Climate 11: 3128-3147.

Swetnam, Thomas W, Craig D Allen, and Julio L Betancourt. 1999. Applied historical ecology: Using the past to manage for the future. Ecological Applications 9: 1189-1206

Theobald, David M. 2001. Land-use dynamics beyond the American urban fringe. Geographical Review 91: 544-564.

Theobald, David M, James R Miller, and NThompson Hobbs. 1997. Estimating the cumulative effects of development on wildlife habitat. Landscape and Urban Planning 39: 25-36.

Toweill, Dale E, and Valerius Geist. 1999. Return to royalty: Wild sheep of North America. Missoula: Boone and Crockett Club and Foundation for North American Wild Sheep.

Turner, Raymond M, Robert H Webb, Janice E Bowers, and James R Hastings. 2003. The changing mile revisited: An ecological study of vegetation change with time in the lower mile of an arid and semiarid region. Tucson: University of Arizona Press.

United States Department of Agriculture Forest Service. 2011. About us. http://www.fs.fed.us/aboutus/. Accessed 30 October 2011.

United States Department of the Interior Bureau of Land Management. 2011. About the BLM. http://www.blm.gov/wo/ st/en/info/About_BLM.html. Accessed 30 October 2011.

United States Department of the Interior Fish and Wildlife Service. 1997. Draft recovery plan for the Stephen's kangaroo rat, Region 1. Portland, Oregon: United States Department of the Interior Fish and Wildlife Service. http://ecos.fws. gov/docs/recovery_plan/970623.pdf. Accessed 30 October 2011.

United States Department of the Interior Fish and Wildlife Service. 2002. Endangered and threatened wildlife and plants: Listing of the Chiricahua leopard frog (Rana chiricahuensis). Federal Register 67: 40790-40811.

United States Department of the Interior Fish and Wildlife. 2004. Endangered and threatened wildlife and plants, Determination of threatened status for the California tiger salamander, and Special Rule Exemption for existing routine ranching activities. Final Rule. Federal Register 69, No. 149, 50 CFR Part 17, RIN 1018-A168, 69 FR 68568.

United States Department of the Interior Fish and Wildlife Service. 2006. Designation of critical habitat for the California red-legged frog and Special Rule Exemption associated with final listing for existing routine ranching activities. Final Rule. Fish and Wildlife Service, Federal Register 71 FR 1924419346.

United States Department of the Interior Fish and Wildlife Service. 2011. ESA Basics: More than 30 years of conserving endangered species. Arlington: United States Department of the Interior Fish and Wildlife Service Endangered Species Program.

Wagner, Guy D, and James M Peek. 2006. Bighorn sheep diet selection and forage quality in central Idaho. Northwest Science 80(4): 246-258.

Weiss, Stuart B. 1999. Cars, cows, and checkerspot butterflies: Nitrogen deposition and management of nutrient-poor grasslands for a threatened species. Conservation Biology 13(6): 1476-1486.

Westoby, Mark. 1980. Elements of a theory of vegetation dynamics in arid rangelands. Israel Journal of Botany 28: 169-194.

doi:10.1186/2041-7136-2-12

Cite this article as: Huntsinger et al: Birds, beasts and bovines: three cases of pastoralism and wildlife in the USA. Pastoralism: Research, Policy and Practice 2012 2:12.

\section{Submit your manuscript to a SpringerOpen ${ }^{\circ}$ journal and benefit from:}

- Convenient online submission

- Rigorous peer review

- Immediate publication on acceptance

- Open access: articles freely available online

- High visibility within the field

- Retaining the copyright to your article

Submit your next manuscript at $>$ springeropen.com 